\title{
The total synthesis of the bioactive natural product plantazolicin A and its
} biosynthetic precursor plantazolicin B.

Sabine Fenner, ${ }^{[a][b]}$ Zoe E. Wilson ${ }^{[a]}$ and Steven V. Ley*[a]

[a] Dr Sabine Fenner, Dr Zoe E. Wilson and Professor Steven V. Ley, Department of Chemistry, University of Cambridge, Lensfield road, CB21EW, Cambridge, UK. E-mail: svl1000@cam.ac.uk

[b] Dr Fenner is now employed by GlaxoSmithKline, Gunnels Wood Rd, SG12NY, Stevenage, UK

\begin{abstract}
Herein we describe our full investigations into the synthesis of the peptide derived natural product plantazolicin A, a compound which demonstrates promising selective activity against the causative agent of anthrax toxicity, and its biosynthetic precursor plantazolicin B. This report particularly focuses on the challenging preparation of the arginine containing thiazole fragment, including the development of a robust, high yielding procedure that avoids the use of sulfurating agents. Extensive studies on the design of a coherent protecting group strategy and the establishment of a step efficient dicyclization/oxidation approach allowed high levels of convergence for the construction of the oxazole fragments. This has led to a unified, highly convergent synthesis for both plantazolicin A and B.
\end{abstract}

\section{Introduction}

The need for new antibiotics, especially those which work by novel mechanisms of action, is undisputed. ${ }^{[1]}$ The rise of antibiotic resistant bacteria is thought, in part, to have been due to the use of broad spectrum antibiotics and therefore narrow spectrum anti-bacterial compounds are garnering increased attention. ${ }^{[1]}$ Natural products have proven to be a significant source of both chemically and mechanistically diverse antibiotics. ${ }^{[2]}$ The isolation of the bioactive molecule plantazolicin A (1) and its biosynthetic precursor ${ }^{[3]}$ plantazolicin B (2) was first reported in 2011 from the Bacillus amyloliquifaciens FZB42 ${ }^{[4]}$, a bacterium which has been recently reclassified as Bacillus velezensis FZB42 ${ }^{[5]}$. These molecules both consist of an unusual linear 14 amino acid sequence which is highly modified to give two polyazole subunits, (figure 1), and plantazolicin A has been predicted to sit in a dynamic hairpin like conformation. ${ }^{[6]}$

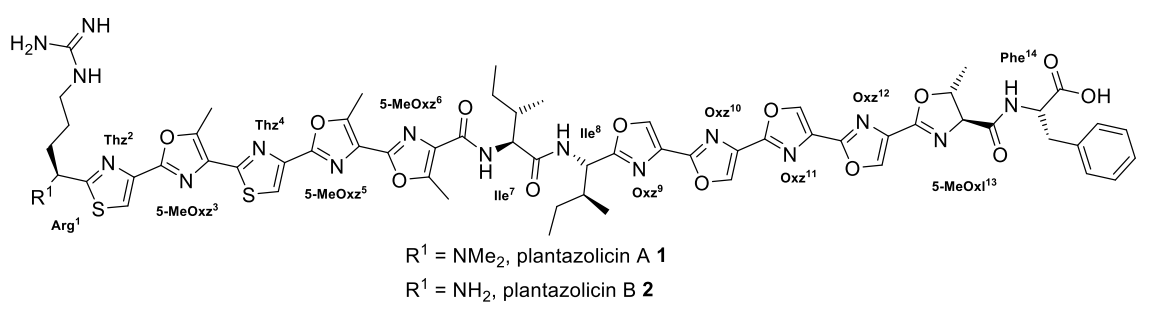

Figure 1. Plantazolicin A (1) and B (2) showing numbering of residues.

It has been observed that the bioactivity of these molecules is dependent on the $N$-terminus dimethylation, with plantazolicin A (1) showing selective and potent activity against Bacillus anthracis, the causative agent of anthrax toxicity ${ }^{[7]}$, while biosynthetic precursor plantazolicin B (2) exhibits reduced biological activity. ${ }^{[8]}$ It is thought that plantazolicin A acts by causing membrane depolarisation and lysis of $B$. anthracis selectively by taking advantage of a locally weakened cell membrane. ${ }^{[7]}$ Additionally, while some truncated analogues of the 
left hand side of 1 have shown respectable activity against $B$. anthracis, they also exhibit reduced selectivity, with their activity thought to occur by a different mechanism. ${ }^{[7 a, 9]}$

The promising bioactivity of plantazolicin A, along with its novel and challenging structure has led to significant interest into the synthesis of these molecules. To date, our recently communicated synthesis of plantazolicin $A$ $(\mathbf{1})^{[10]}$ is the second of three reported total syntheses of this natural product and the only report of the synthesis and full characterisation of biological precursor plantazolicin B (2). Süssmuth et al. reported the synthesis of plantazolicin A (1) in 2013. ${ }^{[11]}$ Moody et al. have recently reported an elegant total synthesis of plantazolicin A (1) based on rhodium-catalysed carbene $\mathrm{N}-\mathrm{H}$ insertion ${ }^{[6]}$. The synthesis and biological evaluation of shortened plantazolicin analogues, and their use to further elucidate the biosynthesis of the natural products, has also been described by both the Mitchell ${ }^{[3 c, 9]}$ and Süssmuth ${ }^{[3 b]}$ groups. Herein we fully disclose our ultimately successful endeavours towards these molecules.

\section{Synthetic strategy}

While there are many potential approaches to the synthesis of these molecules, in terms of convenience and efficiency, careful planning is important to allow the exploitation of affordable and readily available building blocks. Accordingly, our synthetic endeavours were focused on the use of natural amino acids as building blocks where possible. The initial synthetic strategy for the synthesis of plantazolicin A (1) and B (2) was designed to be as convergent as possible, with the natural products being split into two pentacycles by disconnecting at the hinge point between the two isoleucine residues. It was imagined that it would be necessary to form the sensitive oxazolidine ring after the final coupling to avoid its hydrolysis. As the mechanism of the dehydrative cyclization is invertive, this necessitates the incorporation of a L-allo-threonine residue at this position. For the left hand side it was hoped that the arginine containing fragment, which differentiates between plantazolicin $A$ (1) and B (2) could be installed in an advanced stage to ensure maximum convergence between the two syntheses. Our protecting group strategy was based on having protecting groups on the guanidine moiety of the arginine residue and the $C$-terminus which could be simultaneously removed (carboxyl benzyl $(\mathrm{Cbz})$ and benzyl $(\mathrm{Bn})$ ), while the $\mathrm{N}$-terminus was orthogonally protected to allow synthesis of plantazolicin A (1) and B (2) from a common route. It was envisaged that the two thiazole rings could be built by using modified Hantzsch thiazole syntheses, and that oxazole rings could be assembled through iterative amino acid couplings followed by cyclization and oxidation using the methodology of Wipf and Williams ${ }^{[12]}$ (scheme 1). 


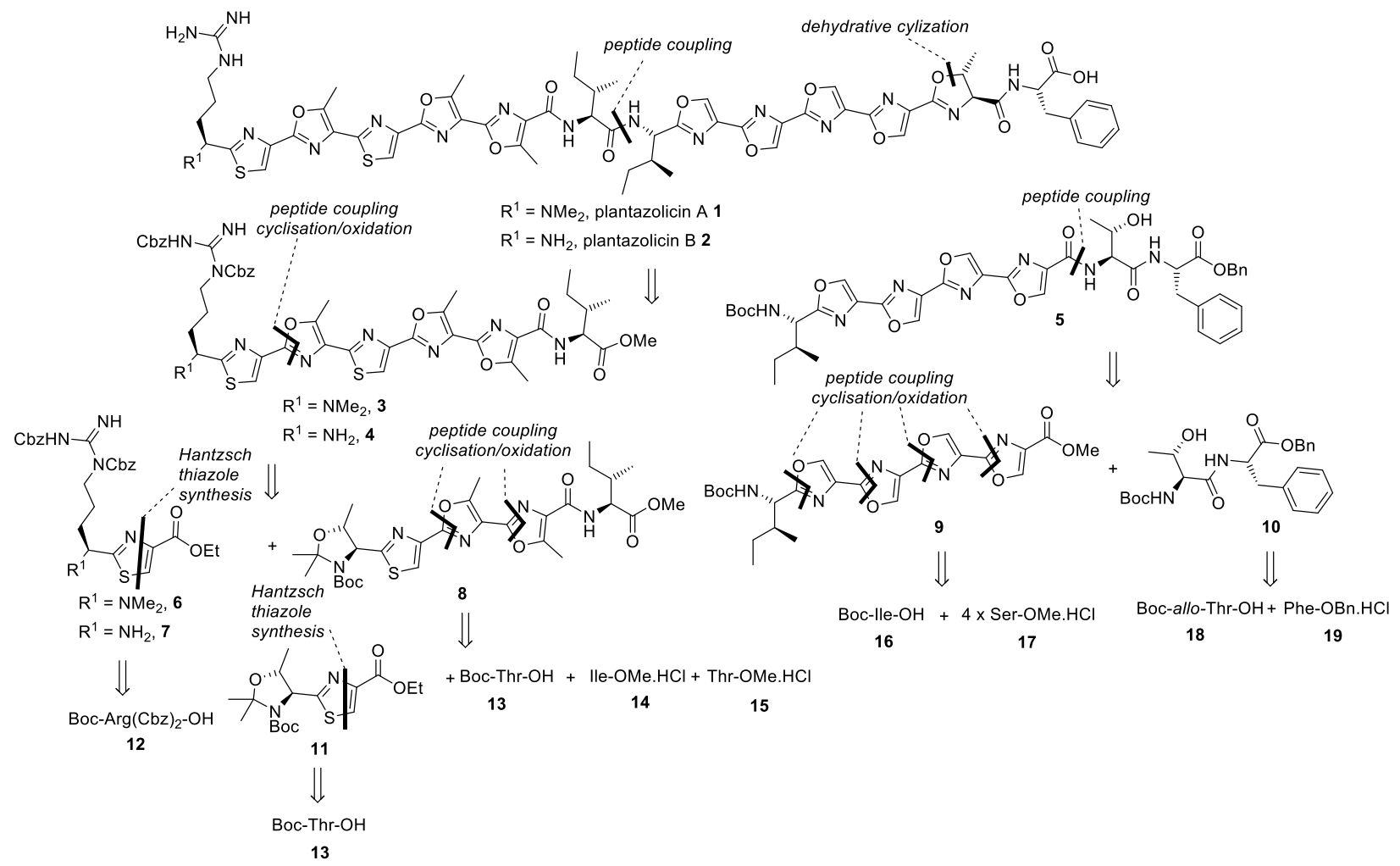

Scheme 1. Initial retrosynthetic strategy for the synthesis of plantazolicin A (1) and B (2).

\section{Results and Discussion}

\section{Synthesis of LHS fragments}

Synthesis of arginine thiazole fragments. One of the most challenging sections of plantazolicin proved to be the synthesis of the two coupling partners which contained arginine derived thiazoles, $\mathbf{6}$ and $\mathbf{7}$. Originally we had decided to simply employ a modified Hantzsch thiazole synthesis ${ }^{[13]}$ for the formation of the desired heterocycle. Differentially protected arginine $\mathbf{1 2}$ was chosen as the starting material as it is commercially available, but should allow for the selective deprotection of the alpha nitrogen to allow $\mathrm{N}$-dimethylation to give access to $\mathbf{6}$, the required coupling partner for plantazolicin A, or left with the Boc-protected alpha nitrogen $\mathbf{7}$ for plantazolicin B (scheme 2).

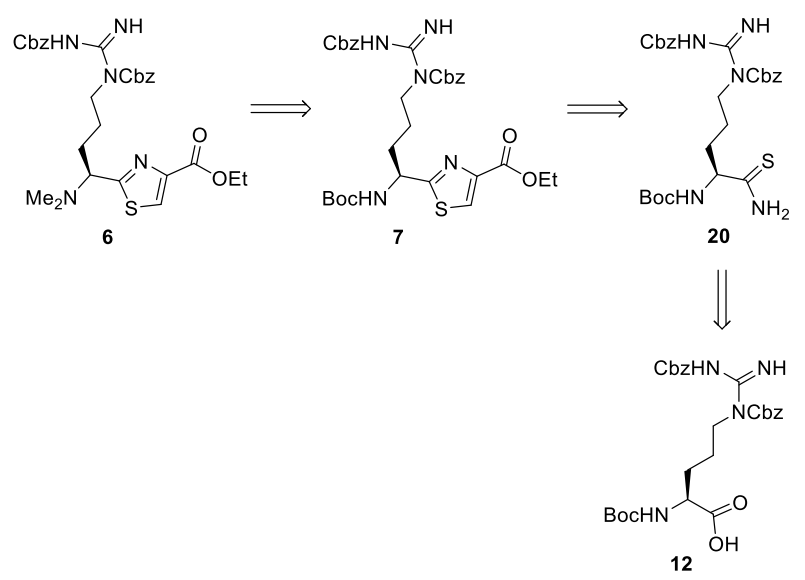

Scheme 2. Initial retrosynthesis for arginine derived thiazoles $\mathbf{6}$ and $\mathbf{7}$. 
The route began with the amidation of Boc- $\mathrm{Arg}(\mathrm{Cbz})_{2}-\mathrm{OH} 12$ with the crude amide being directly converted to the thioamide using the sulfurating agent Belleau's reagent ${ }^{[14]}$ in an acceptable $77 \%$ yield. The key modified Hantzch thiazole formation ${ }^{[13]}$ was then carried out to afford thiazole $\mathbf{7}$ in a modest $33 \%$ yield. Pleasingly, it was found that the alpha nitrogen of the arginine residue could be deprotected using trifluoroacetic acid (TFA) and although $\mathrm{N}$-methylation was at first unsuccessful when attempted using the Eschweiler-Clarke reaction ${ }^{[15]}$, it was found that reductive amination could be carried out using sodium cyanoborohydride ${ }^{[16]}$ to afford dimethyl arginine thiazole 6 in 54\% yield (scheme 3). However, the overall yield of only 25\% for thiazole 7 was limiting, and additionally it was found that the yield of the thiazole formation tended to be variable when it was carried out on scale, necessitating an alternative approach for thiazole $\mathbf{7 .}$

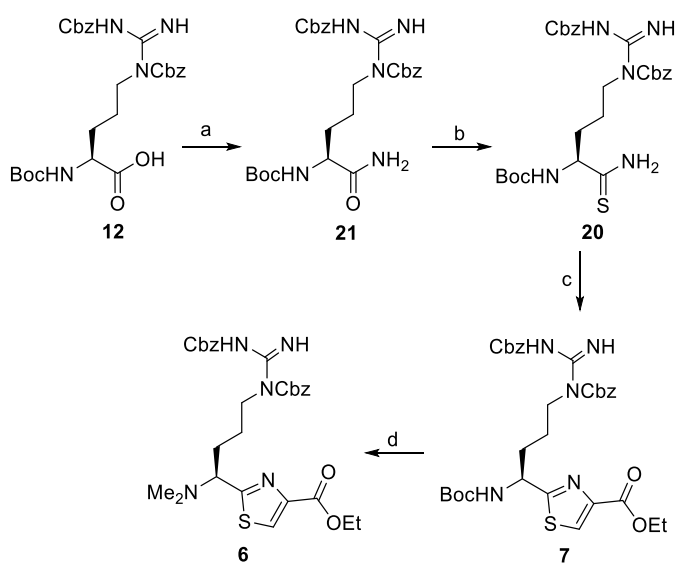

Scheme 3. Modified Hantzsch synthesis of arginine thiazoles 6 and 7. Reagents and conditions: a) i. isobutylchloroformate, $\mathrm{NMM}, \mathrm{THF},-20^{\circ} \mathrm{C}, 10 \mathrm{~min}$, ii. $\mathrm{NH}_{4} \mathrm{OH}\left(35 \%\right.$ in $\mathrm{H}_{2} \mathrm{O}$ ), $0{ }^{\circ} \mathrm{C}, 5.5 \mathrm{~h}$; b) Belleau's reagent, THF $0{ }^{\circ} \mathrm{C}$ - rt, $2.5 \mathrm{~h}, 77 \%$; c) ethyl bromopyruvate, $\mathrm{KHCO}_{3}, \mathrm{DME},-15^{\circ} \mathrm{C}, 5 \mathrm{~min}$ then trifluoroacetic anhydride, 2,6lutidine, $\mathrm{DME},-15^{\circ} \mathrm{C}, 4 \mathrm{~h}, 33 \%$; d) i. TFA, $\mathrm{CH}_{2} \mathrm{Cl}_{2}, \mathrm{rt}, 3.5$ h, ii. $37 \%$ aq. $\mathrm{CH}_{2} \mathrm{O}, \mathrm{CH}_{3} \mathrm{OH}$, rt, 40 min then $\mathrm{NaBH}_{3} \mathrm{CN}$, rt, $14.5 \mathrm{~h}, 54 \%$. NMM $=\mathrm{N}$-methylmorpholine.

The condensation of cysteine ethyl ester (22) with an amino acid derived aldehyde ${ }^{[17]}$ allows the formation of thiazolidines from amino acid derived precursors without requiring the use of unpleasant sulfurating reagents. It was envisaged that if arginine derived aldehyde $\mathbf{2 3}$ could be accessed, this would provide a rapid access to thiazole $\mathbf{7}$ from readily available starting materials (scheme 4).

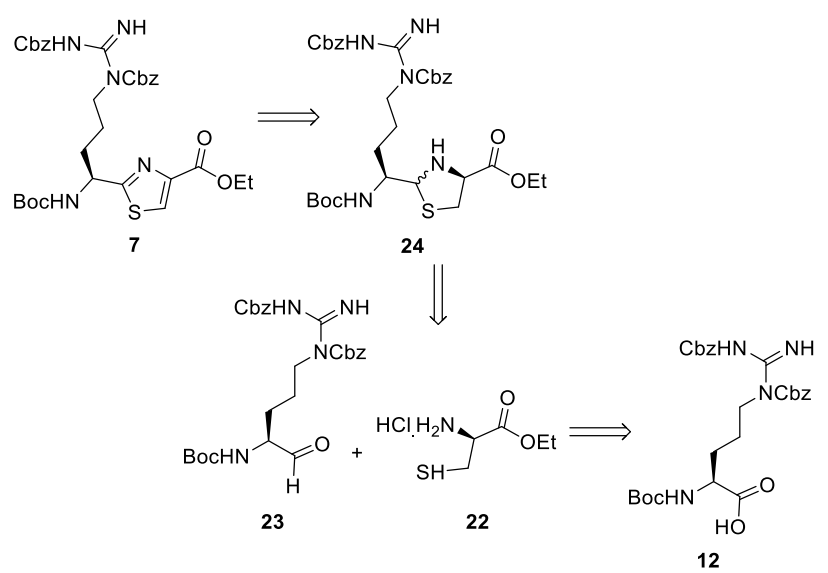

Scheme 4. Alternative retrosynthesis for thiazole 7. 
Straightforward coupling of differentially protected arginine $\mathbf{1 2}$ with N,O-dimethylhydroxylamine $\mathbf{2 5}$ afforded amide 26, which could then be reduced to the required amino acid derived aldehyde quantitatively. The crude aldehyde was directly coupled with cysteine ethyl ester hydrochloride $\mathbf{2 2}$ in biphasic solution with substoichiometric potassium bicarbonate ${ }^{[17 \mathrm{a}]}$, to afford the thiazolidine $\mathbf{2 4}$. This could then be oxidised using manganese dioxide, to reproducibly afford thiazole $\mathbf{7}$ in four steps (three purifications) and an overall yield of $52 \%$ (scheme 5).

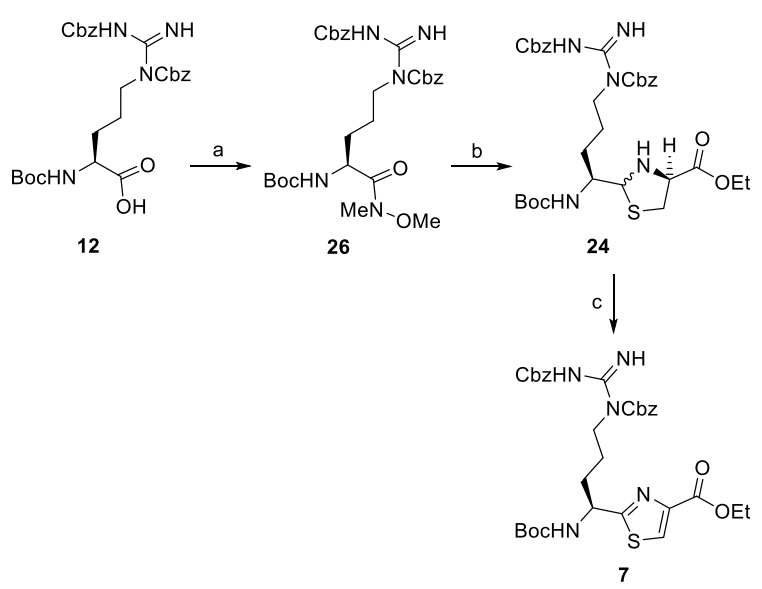

Scheme 5. Alternative synthesis of thiazole 7. Reagents and conditions: a) $\mathrm{CH}_{3} \mathrm{ONHCH}_{3} \cdot \mathrm{HCl} 25, \mathrm{~N}^{i} \mathrm{Pr}_{2} \mathrm{Et}, \mathrm{HOBt}$, $\mathrm{EDCl}, \mathrm{CH}_{2} \mathrm{Cl}_{2}, \mathrm{rt}, 16 \mathrm{~h}, 96 \%$, b) i. DIBAL-H, $\mathrm{CH}_{2} \mathrm{Cl}_{2},-78^{\circ} \mathrm{C}, 40 \mathrm{~min}$, ii. Cys-OEt. $\mathrm{HCl}$ 22, $\mathrm{KHCO}{ }_{3}, \mathrm{MeOH} /$ toluene/ $\mathrm{H}_{2} \mathrm{O}$, rt, $15 \mathrm{~h}, 81 \%$; c) $\mathrm{MnO}_{2}$, toluene, $80^{\circ} \mathrm{C}, 24 \mathrm{~h}, 67 \%$. DIBAL-H = diisobutylaluminium hydride.

As the synthesis progressed, it was found that the hydrolysis of the ethyl ester of $\mathbf{6}$ and $\mathbf{7}$ to afford the free acid was problematic, with significant amounts of degradation being seen under a range of conditions for the hydrolysis. To avoid this problem, cysteine methyl ester hydrochloride $\mathbf{2 7}$ was used as the aldehyde coupling partner in the established route to afford methyl ester protected thiazoles $\mathbf{2 8}$ and $\mathbf{2 9}$ (scheme 6).

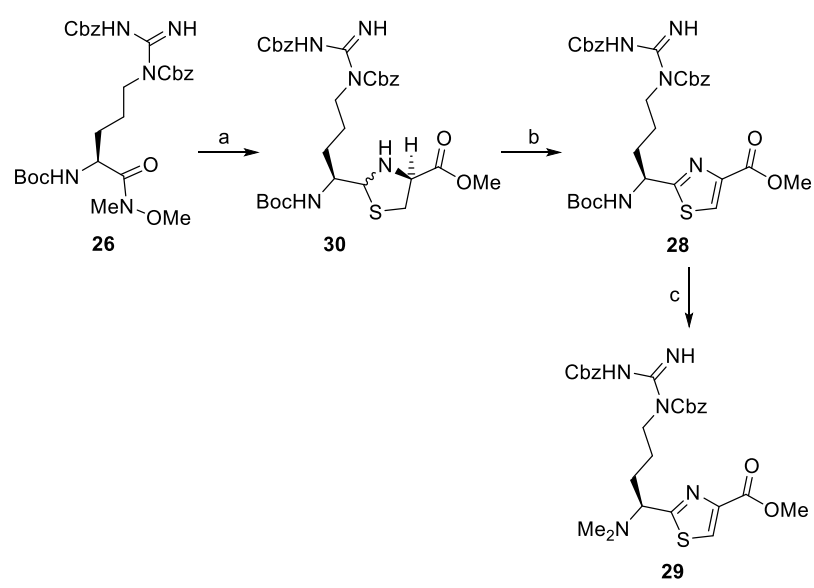

Scheme 6. Synthesis of arginine thiazole methyl esters 28 and 29. Reagents and conditions: a) i. DIBAL-H, $\mathrm{CH}_{2} \mathrm{Cl}_{2}$, $-78{ }^{\circ} \mathrm{C}, 50 \mathrm{~min}$, ii. Cys-OMe. $\mathrm{HCl} 27, \mathrm{KHCO}_{3}, \mathrm{MeOH} /$ toluene/ $\mathrm{H}_{2} \mathrm{O}, \mathrm{rt}, 15.5 \mathrm{~h}, 75 \%$; b) $\mathrm{MnO}_{2}$, toluene, $80{ }^{\circ} \mathrm{C}, 19.5 \mathrm{~h}$, $57 \%$; c) i. TFA, $\mathrm{CH}_{2} \mathrm{Cl}_{2}$, rt, 5 h, ii. $37 \%$ aq. $\mathrm{CHO}, \mathrm{CH}_{3} \mathrm{OH}, \mathrm{rt}, 1 \mathrm{~h}$ then $\mathrm{NaBH}_{3} \mathrm{CN}, \mathrm{rt}, 18 \mathrm{~h}, 52 \%$. 
Additionally, as the protecting group strategy developed, it became necessary to have the arginine guanidine nitrogens protected using tert-butyloxycarbonyl protecting group. Initially this was accomplished by removing the nitrogen protecting groups from the four synthesised thiazoles, 6, 7, 28 and $\mathbf{2 9}$, and directly reprotecting them using di-tert-butyl dicarbonate and diisopropyethylamine to afford the di- (31 and 32) or tri- (33 and $\mathbf{3 4}$ ) Boc protected thiazoles in eight or six steps respectively (scheme 7).

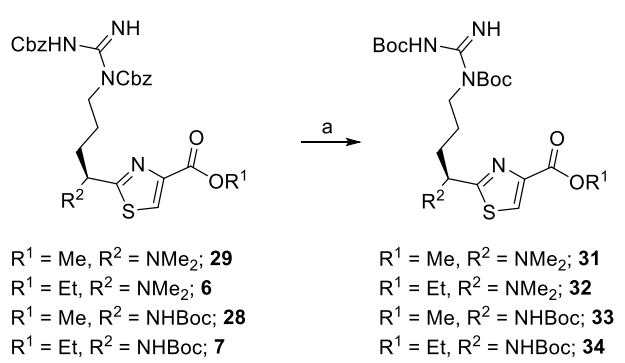

Scheme 7. Swapping protection on arginine thiazoles. Reagents and conditions: a) i. $\mathrm{PdCl}_{2}, \mathrm{H}_{2}, \mathrm{MeOH}, 45 \mathrm{~min}$ (31 and 34)/50 min (32)/30 min (33), ii. $\mathrm{Boc}_{2} \mathrm{O}, \mathrm{N}^{i} \mathrm{Pr}_{2} \mathrm{Et}, \mathrm{CH}_{2} \mathrm{Cl}_{2}, \mathrm{rt}, 4$ days (31, 32 and 34)/ 6 days (33), $31=86 \%$, $32=24 \%, 33=87 \%, 34=87 \%$.

A more step efficient method for the preparation of the guanidine Boc protected thiazoles was next attempted, starting from carboxybenzyl arginine 35. The free acid was converted to the methyl ester and the crude ester Boc protected as previously established. This afforded a separable 4.7:1 ratio of the $N \delta, N \omega^{\prime}$ (31a) and $N \omega, N \omega^{\prime}$ (31b) protected isomers in overall $57 \%$ yield. Both isomers could then be progressed through to the thiazole. It was found that esters $\mathbf{3 6}$ could be reduced to the required aldehyde without over-reduction to the corresponding alcohol, then directly used in the thiazolidine formation as previously employed. However, it was found that removal of the $\mathrm{Cbz}$ group from $\mathrm{Na}$ with retention of the Boc protection on the guanidine functionality was challenging. When hydrogenation of thiazole 37a was attempted using palladium" chloride, buffered with potassium carbonate to ensure retention of the Boc protection, only a small amount of the desired $\mathrm{Cbz}$ deprotected product was formed, which could then be $\mathrm{N}$-dimethylated as previously to afford only $18 \%$ of 31 a, with $42 \%$ of starting material 37 a also being recovered. This indicated that the Cbz deprotection was in fact mediated by the acid produced when palladium" chloride was reduced to palladium ${ }^{0}$, rather than solely by hydrogenation.

When palladium" chloride was used unbuffered, while the Na was fully deprotected, the Boc groups were also partially deprotected. While pleasingly it was seen that controlling the $\mathrm{pH}$ of the reaction mixture allowed for the selective $N$-methylation at $N \alpha$, this did necessitate an additional Boc reprotection step to afford the two differently protected isomers of thiazole $\mathbf{3 1}$ (scheme 8).

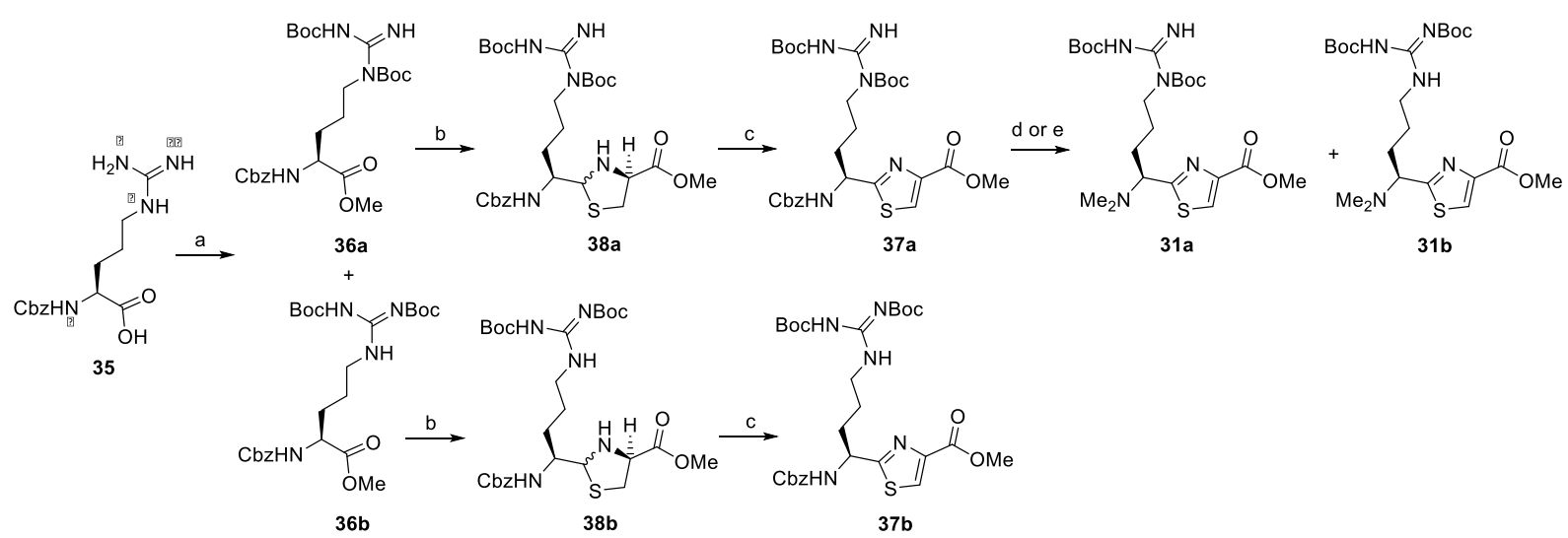


Scheme 8. Alternative protecting group strategy for arginine thiazoles. Reagents and conditions: a) i. $\mathrm{Si}\left(\mathrm{CH}_{3}\right)_{3} \mathrm{Cl}, \mathrm{MeOH}$, rt, 18.5 h, ii. $\mathrm{Boc}_{2} \mathrm{O}, \mathrm{N}^{i} \mathrm{Pr}_{2} \mathrm{Et}, \mathrm{MeOH}, \mathrm{CH}_{2} \mathrm{Cl}_{2}, \mathrm{rt}, 6$ days, $47 \%$ (36a) and $10 \%$ (36b); b) i. DIBAL-H, $\mathrm{CH}_{2} \mathrm{Cl}_{2},-78^{\circ} \mathrm{C}$, $3 \mathrm{~h} 10 \mathrm{~min}(38 \mathrm{a}) / 3 \mathrm{~h}$ (38b), ii. Cys-OMe. $\mathrm{HCl} 27, \mathrm{KHCO}_{3}$, toluene $/ \mathrm{H}_{2} \mathrm{O} / \mathrm{MeOH}$ (36b only), rt, $21 \mathrm{~h} \mathrm{(38a)/22} \mathrm{h} \mathrm{(38b),} \mathrm{38a}=64 \%, 38 \mathrm{~b}=54 \% ; \mathrm{c}) \mathrm{MnO}_{2}$, toluene, $80{ }^{\circ} \mathrm{C}, 24 \mathrm{~h}(37 \mathrm{a}) / 20 \mathrm{~h}$ (37b), 37a = 54\%, 37b = 17\%; d) i. $\mathrm{K}_{2} \mathrm{CO}_{3}, \mathrm{PdCl}_{2}, \mathrm{H}_{2}, \mathrm{MeOH}, \mathrm{rt}, 3 \mathrm{~h}$, ii. $37 \%$ aq. $\mathrm{CHO}, \mathrm{MeOH}, \mathrm{rt}, 1 \mathrm{~h}$ then $\mathrm{NaBH}_{3} \mathrm{CN}$, rt, 20.5 h, $18 \%$ (31a) and 42\% (37a); e) i. $\mathrm{PdCl}_{2}, \mathrm{H}_{2}, \mathrm{MeOH}, \mathrm{rt}, 1$ h, ii. 37\% aq. $\mathrm{CH}_{2} \mathrm{O}, \mathrm{MeOH}$, rt, $1 \mathrm{~h}$ then $\mathrm{NaBH}_{3} \mathrm{CN}, \mathrm{rt}, 20.5 \mathrm{~h}$, iii. $\mathrm{Boc}_{2} \mathrm{O}, \mathrm{N}^{\prime} \mathrm{Pr}_{2} \mathrm{Et}, \mathrm{MeOH}, \mathrm{CH}_{2} \mathrm{Cl}_{2}, \mathrm{rt}, 4$ days, 36\% (31a) and 23\% (31b).

Boc- $N-\operatorname{Arg}\left(\mathrm{Boc}_{2}\right)-\mathrm{OH} 39$ is commercially available, which meant that both the methyl (33) and ethyl (34) esters of the tri-boc thiazole could be synthesised in just four steps (three purifications) by the established route. The $\mathrm{N}$-dimethyl thiazoles could then be accessed by Boc deprotection, reductive amination at the $N \alpha$ position and Boc reprotection. Global Boc deprotection was first attempted using trifluoroacetic acid, which afforded an $11 \%$ yield of the desired dimethyl thiazole 31a after reductive amination and reprotection. Pleasingly, however, it was found that deprotection using anhydrous hydrochloric acid followed by reductive amination and reprotection afforded a $52 \%$ yield of thiazole $\mathbf{3 1}$ as a separable 35:17 (a:b) mixture of the two protected isomers (scheme 9).

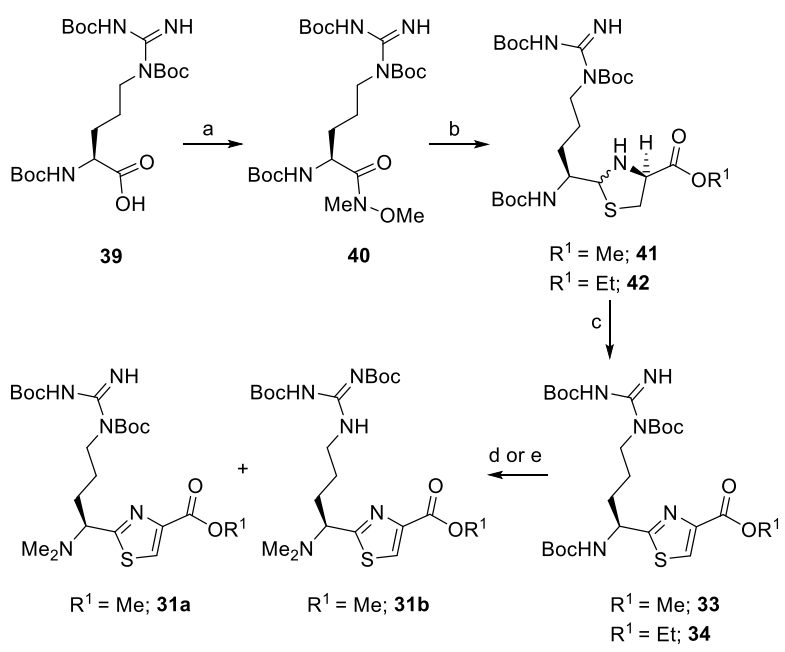

Scheme 9. Synthesis of arginine thiazoles from tri-Boc arginine. Reagents and conditions: a) $\mathrm{CH}_{3} \mathrm{ONHCH}_{3} . \mathrm{HCl} 25, \mathrm{~N}^{i} \mathrm{Pr}_{2} \mathrm{Et}, \mathrm{HOBt}, \mathrm{EDCl}, \mathrm{CH}_{2} \mathrm{Cl}_{2}, \mathrm{rt}, 16 \mathrm{~h}, 99 \%$, b) i. DIBAL-H, $\mathrm{CH}_{2} \mathrm{Cl}_{2},-78{ }^{\circ} \mathrm{C}, 1 \mathrm{~h}$, ii. Cys-OMe. $\mathrm{HCl} 27$ (41) or Cys-OEt. $\mathrm{HCl} 22$ (42), $\mathrm{KHCO}_{3}, \mathrm{MeOH} /$ toluene/ $\mathrm{H}_{2} \mathrm{O}, \mathrm{rt}, 41.5 \mathrm{~h}$ (41)/19 h (42), 41 = 78\%, 42 = 73\%; c) $\mathrm{MnO}_{2}$, toluene, $80{ }^{\circ} \mathrm{C}, 15 \mathrm{~h}(33) / 21 \mathrm{~h}(34), 33=48 \%, 34=59 \% ;$ d) i. TFA, $\mathrm{CH}_{2} \mathrm{Cl}_{2}$, rt, 1 h, ii. $37 \%$ aq. $\mathrm{CH}_{2} \mathrm{O}, \mathrm{CH}_{3} \mathrm{OH}$, rt, 1.5 h then $\mathrm{NaBH}_{3} \mathrm{CN}$, rt, 20 h, iii. $\mathrm{Boc}_{2} \mathrm{O}, \mathrm{N}^{i} \mathrm{Pr}_{2} \mathrm{Et}$, rt, 4 days, $11 \%$ (31a); e) i. $\mathrm{HCl}, 1$,4-dioxane, rt, 1 h, ii. $37 \%$ aq. $\mathrm{CH}_{2} \mathrm{O}, \mathrm{CH}_{3} \mathrm{OH}, \mathrm{rt}, 1 \mathrm{~h}$ then $\mathrm{NaBH}_{3} \mathrm{CN}$, rt, $15.5 \mathrm{~h}$, iii. $\mathrm{Boc}_{2} \mathrm{O}, \mathrm{N}^{\prime} \mathrm{Pr}_{2} \mathrm{Et}, \mathrm{CH}_{2} \mathrm{Cl}_{2}, \mathrm{rt}, 4$ days, 35\% (31a) and 17\% (31b). $\mathrm{HOBt}=1$-hydrobenzotriazole, $\mathrm{EDCl}=\mathrm{N}$ (3-dimethylaminopropyl)- $N$ "-ethyl-carbodiimide hydrochloride.

In an effort to develop a more step efficient approach to the $\mathrm{N}$-dimethyl thiazoles, the preparation of protected $\mathbf{N}$-dimethyl arginine $\mathbf{4 3}$ was next attempted. Reductive amination then protection of the free base of arginine methyl ester hydrochloride $\mathbf{4 4}$ resulted in a low $5 \%$ yield of the desired product $\mathbf{4 3 a}$. Pleasingly however arginine $\mathbf{4 5}$ could be $\mathbf{N} \alpha$-dimethylated by a literature procedure ${ }^{[18]}$, the acid esterified and Boc protection carried out to afford a $62 \%$ yield of $\mathbf{4 3}$ as a separable 2.1:1 (a:b) mixture of the two regioisomers. It was found that 43 a could be reduced, coupled with cysteine 
methyl ester hydrochloride $\mathbf{2 7}$ and oxidised to afford thiazole $\mathbf{3 1 a}$ in $14 \%$ yield (scheme 10). While this route required one less step than that of scheme 9 , the overall yield was significantly lower (6\% vs $13 \% 31 \mathrm{a}$ and $6 \% 31 \mathrm{~b})$ so it was decided to use the route from Boc- $N-\operatorname{Arg}\left(\mathrm{Boc}_{2}\right)-\mathrm{OH} 39$ for the synthesis of both the target thiazoles.

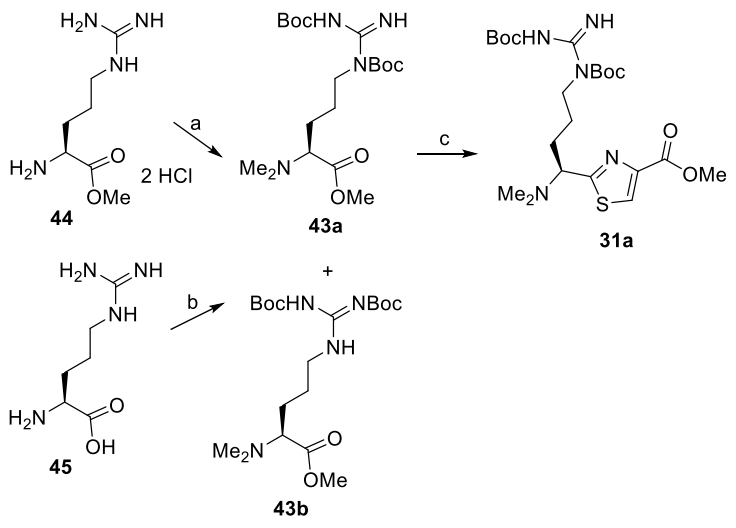

Scheme 10. Direct synthesis of dimethyl arginine thiazole 31a. Reagents and conditions: a) i. Ambersep $900-\mathrm{OH}, \mathrm{MeOH}, \mathrm{rt}, 5 \mathrm{~min}$, ii. $\mathrm{CH}_{2} \mathrm{O}, \mathrm{MeOH}, \mathrm{rt}, 1 \mathrm{~h} 40$ min then $\mathrm{NaBH}_{3} \mathrm{CN}, \mathrm{rt}, 18 \mathrm{~h}$, iii. $\mathrm{Boc}_{2} \mathrm{O}, \mathrm{N}^{\prime} \mathrm{Pr}_{2} \mathrm{Et}, \mathrm{MeOH}, \mathrm{CH}_{2} \mathrm{Cl}_{2}, \mathrm{rt}, 7$ days, 5\% (43a); b) i. $37 \%$ aq. $\mathrm{CHO}, \mathrm{NaBH}_{3} \mathrm{CN}, \mathrm{NaOAc}, \mathrm{H}_{2} \mathrm{O}, \mathrm{rt}$, 16.5 h, ii. $\mathrm{Si}\left(\mathrm{CH}_{3}\right)_{3} \mathrm{Cl}, \mathrm{MeOH}$, rt, $18 \mathrm{~h}$, iii. $\mathrm{Boc}_{2} \mathrm{O}, \mathrm{N}^{\prime} \mathrm{Pr}_{2} \mathrm{Et}, \mathrm{MeOH}, \mathrm{CH}_{2} \mathrm{Cl}_{2}, \mathrm{rt}, 13$ days, 42\% (43a) and 20\% (43b); c) i. DIBAL-H, $\mathrm{CH}_{2} \mathrm{Cl}_{2},-78{ }^{\circ} \mathrm{C}, 1 \mathrm{~h}$, ii. Cys-OMe. $\mathrm{HCl} 27, \mathrm{KHCO}_{3}$, toluene/ $\mathrm{H}_{2} \mathrm{O}, \mathrm{rt}, 18 \mathrm{~h}$, iii. $\mathrm{MnO}_{2}$, toluene, $80^{\circ} \mathrm{C}, 23 \mathrm{~h}, 14 \%$.

Synthesis of threonine thiazole fragment. Known threonine derived thiazole $11^{[19]}$ was obtained from Boc-threonine $\mathbf{1 3}$ by the same approach as was applied to the synthesis of the arginine thiazoles to afford $\mathbf{1 1}$ in $\mathbf{4 2 \%}$ overall yield (scheme 11 ).

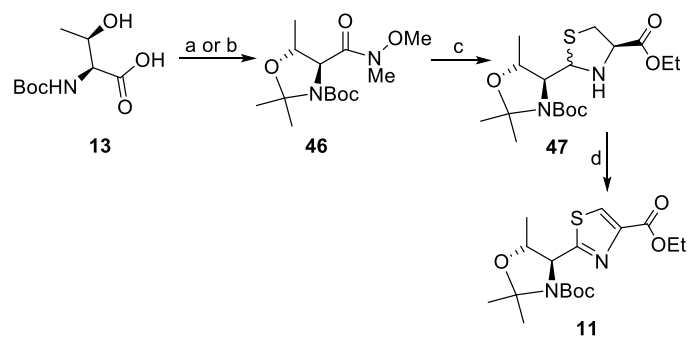

Scheme 11. Synthesis of threonine thiazole 11. Reagents and conditions: a) i. 2,2-dimethoxypropane, PPTS, THF, reflux, 15 h, ii. $\mathrm{CH}_{3} \mathrm{ONHCH}_{3} . \mathrm{HCl} 25, \mathrm{~N}^{\prime} \mathrm{Pr}_{2} \mathrm{Et}, \mathrm{HOBt}, \mathrm{EDCl}, \mathrm{CH}_{2} \mathrm{Cl}_{2}, \mathrm{rt}, 21 \mathrm{~h}, 49 \%$; b) i. $\mathrm{CH}_{3} \mathrm{ONHCH}_{3} . \mathrm{HCl} 25, \mathrm{~N}^{\prime} \mathrm{Pr}_{2} \mathrm{Et}, \mathrm{HOBt}, \mathrm{EDCl}, \mathrm{CH}_{2} \mathrm{Cl}_{2}, \mathrm{rt}, 22$ h, ii. 2,2-dimethoxypropane, PPTS, THF, reflux, $18 \mathrm{~h}, 86 \%$; c) i. DIBAL-H, $\mathrm{CH}_{2} \mathrm{Cl}_{2},-78{ }^{\circ} \mathrm{C}, 30 \mathrm{~min}$, ii. Cys-OEt. $\mathrm{HCl} 22, \mathrm{KHCO}_{3}$, toluene $/ \mathrm{H}_{2} \mathrm{O} / \mathrm{MeOH}, \mathrm{rt}$, $15 \mathrm{~h}, 83 \%$; d) $\mathrm{MnO}_{2}$, toluene, $80{ }^{\circ} \mathrm{C}, 24 \mathrm{~h}, 59 \%$. PPTS = para-toluene sulphonate.

Synthesis of tri-azole. The route to tri-azole $\mathbf{8}$ started with the hydrolysis of the ethyl ester of threonine thiazole 11 using lithium hydroxide before it was coupled with threonine methyl ester hydrochloride $\mathbf{1 5}$ to afford $\mathbf{4 8}$ in $\mathbf{5 7 \%}$ yield. Cyclization was effected using the fluorinating reagent Deoxo-Fluor and oxidation with bromotrichloromethane $\left(\mathrm{BrCCl}_{3}\right)$ and 1,8-diazabicycloundec-7-ene (DBU) according to a one-pot method of Wipf and Williams ${ }^{[12]}$ to afford dicycle $\mathbf{4 9}$ in $43 \%$ yield. The synthesis of di-cycle $\mathbf{4 9}$ in $\mathbf{5 4 \%}$ overall yield from $\mathbf{4 8}$ using flow chemistry has been previously 
reported by this group. ${ }^{[20]}$ Di-cycle $\mathbf{4 9}$ was then coupled with Boc deprotected threonine-isoleucine dipeptide $\mathbf{5 0}$ before cyclization and oxidation to afford a modest $15 \%$ yield of tri-azole $\mathbf{8}$ (scheme 12). The final oxidation was also attempted using manganese dioxide, however this only resulted in partial conversion to the desired product, even with large excesses of oxidant.

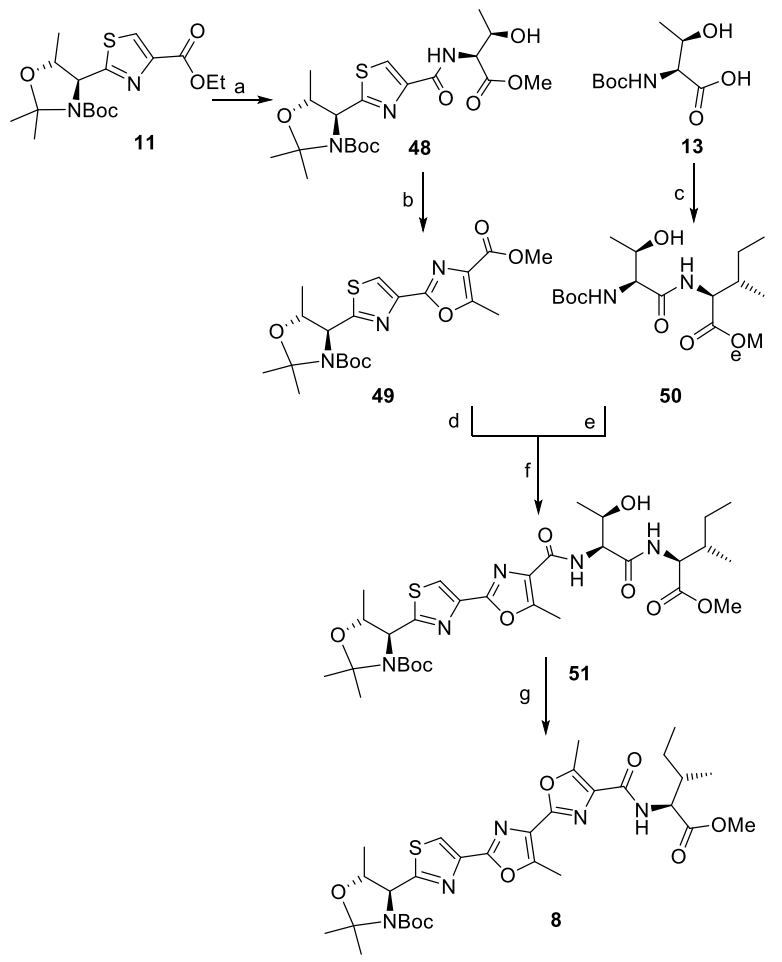

Scheme 12. Linear synthesis of tri-azole 8. Reagents and conditions: a) i. $\mathrm{LiOH} . \mathrm{H}_{2} \mathrm{O}, \mathrm{THF} / \mathrm{H}_{2} \mathrm{O}, \mathrm{O}^{\circ} \mathrm{C}-$ rt, 13 h, ii. Thr-OMe.HCl 15, Ní $\mathrm{Pr}_{2} \mathrm{Et}$, $\mathrm{HOBt}, \mathrm{EDCl}, \mathrm{CH}_{2} \mathrm{Cl}_{2}, \mathrm{rt}, 17 \mathrm{~h}, 57 \%$; b) Deoxo-Fluor ${ }^{\circ} \mathrm{CH}_{2} \mathrm{Cl}_{2},-20^{\circ} \mathrm{C}$, $2 \mathrm{~h}$ then DBU, $\mathrm{BrCCl}_{3},-20{ }^{\circ} \mathrm{C}-0{ }^{\circ} \mathrm{C}, 60 \mathrm{~h}, 43 \%$; c) lle-OMe. $\mathrm{HCl} 14, \mathrm{~N}^{\prime} \mathrm{Pr}_{2} \mathrm{Et}, \mathrm{HOBt}, \mathrm{EDCl}, \mathrm{CH}_{2} \mathrm{Cl}_{2}, \mathrm{rt}, 17 \mathrm{~h}$, 99\%; d) LiOH. $\mathrm{H}_{2} \mathrm{O}$, THF $/ \mathrm{H}_{2} \mathrm{O}, 0{ }^{\circ} \mathrm{C}-\mathrm{rt}, 18 \mathrm{~h}$; e) anhydrous $\mathrm{HCl}, 1$, 4-dioxane, rt, $45 \mathrm{~min}$; f) $\mathrm{N}^{\prime} \mathrm{Pr}_{2} \mathrm{Et}$, $\mathrm{HOBt}, \mathrm{EDCl}, \mathrm{CH}_{2} \mathrm{Cl}_{2}, \mathrm{rt}, 19 \mathrm{~h}, 31 \%$ (3 steps); g) Deoxo-Fluor , $\mathrm{CH}_{2} \mathrm{Cl}_{2},-20^{\circ} \mathrm{C}, 2 \mathrm{~h}$ then $\mathrm{DBU}, \mathrm{BrCCl}_{3}$, $20^{\circ} \mathrm{C}-0{ }^{\circ} \mathrm{C}, 48 \mathrm{~h}, 15 \%$.

In order to facilitate a more convergent approach to tri-azole $\mathbf{8}$ it was next decided to determine whether the two cyclization and oxidation steps could be carried out concurrently. Tripeptide $\mathbf{5 2}$ was synthesised in $80 \%$ yield by straightforward peptide couplings using EDCl and HOBt (see supporting information). This was coupled with threonine thiazole $\mathbf{1 1}$ to give cyclization precursor $\mathbf{5 3}$. It was found that by increasing the reaction time and the equivalents of $\mathrm{BrCCl}_{3}$ and $\mathrm{DBU}$ used the dicyclization and oxidation could be affected in $64 \%$ yield (scheme 13 ).

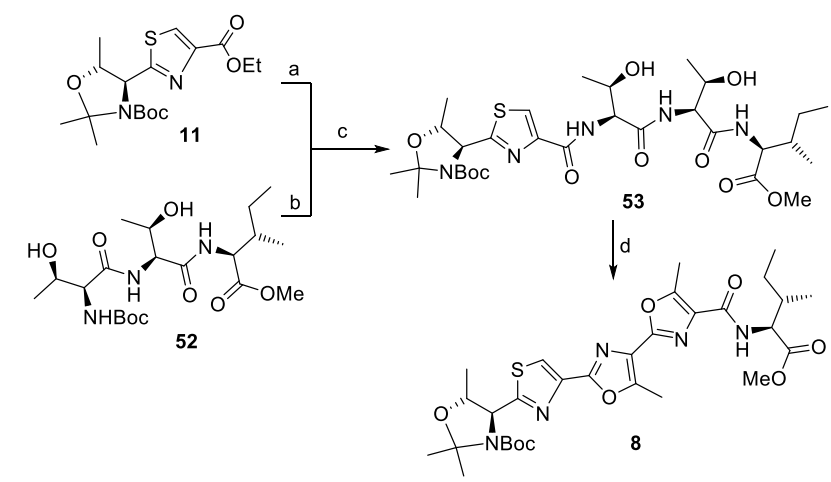


Scheme 13. Convergent synthesis of tri-azole 8. Reagents and conditions: a) LiOH. $\mathrm{H}_{2} \mathrm{O}, \mathrm{MeOH} / \mathrm{H}_{2} \mathrm{O}$, $\mathrm{rt}, 3 \mathrm{~h}$; b) anhydrous $\mathrm{HCl}, 1$,4-dioxane, rt, $30 \mathrm{~min}$; c) $\mathrm{N}^{i} \mathrm{Pr}_{2} \mathrm{Et}, \mathrm{HOBt}, \mathrm{EDCl}, \mathrm{CH}_{2} \mathrm{Cl}_{2}, \mathrm{rt}, 17.5 \mathrm{~h}, 71 \%$; d) Deoxo-Fluor , $\mathrm{CH}_{2} \mathrm{Cl}_{2},-20{ }^{\circ} \mathrm{C}, 2.5 \mathrm{~h}$ then $\mathrm{DBU}, \mathrm{BrCCl}_{3}$ (portionwise), $-20^{\circ} \mathrm{C}-0{ }^{\circ} \mathrm{C}, 110 \mathrm{~h}, 64 \%$.

Completion of LHS fragments. Next attention turned to the completion of the two left hand side fragments $\mathbf{5 4}$ and $\mathbf{5 5}$. While the $\mathrm{N}$-Boc deprotections were routinely effected using anhydrous hydrochloric acid in dioxane, it was found that the addition of water to the reaction mixture allowed the simultaneous removal of the Boc protection and the acetal from 8, whereas when anyhydrous $\mathrm{HCl}$ was used only the Boc protection was lost. It was found that the methyl esters of $\mathbf{3 1}$ and $\mathbf{3 3}$ could be carefully hydrolysed at low temperature and the deprotected molecules coupled using 1[bis(dimethylamino)methylene]-1H-1,2,3-triazolo[4,5-b]pyridinium 3-oxide hexafluorophosphate (HATU) and diisopropylethylamine to afford cyclization precursors $\mathbf{5 6}$ and $\mathbf{5 7}$. The established cyclization/oxidation conditions were then employed to afford the pentacycles $\mathbf{5 4}$ and $\mathbf{5 5}$ with overall yields of $8 \%$ and $12 \%$ respectively for the longest linear pathways (scheme 14 ).

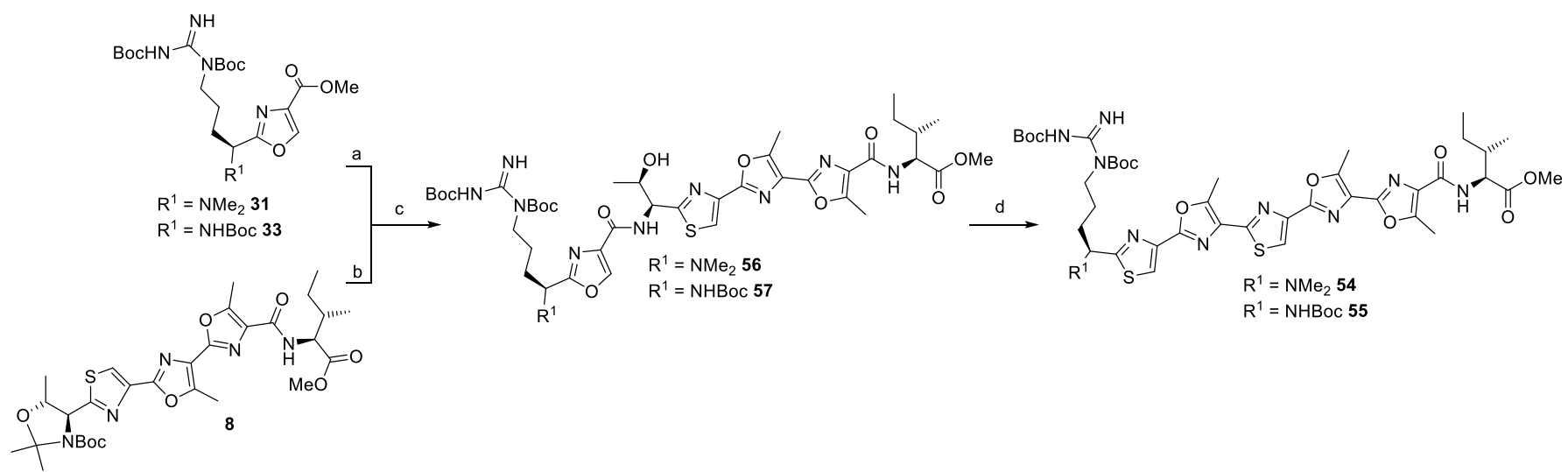

Scheme 14. Completion of left hand fragments $\mathbf{5 4}$ and 55. Reagents and conditions: a) LiOH. $\mathrm{H}_{2} \mathrm{O}$, $\mathrm{MeOH} / \mathrm{H}_{2} \mathrm{O}, 0{ }^{\circ} \mathrm{C}, 1.5 \mathrm{~h}$; b) $\mathrm{HCl}$ (dioxane/ $\mathrm{H}_{2} \mathrm{O}$ ), 1,4-dioxane, rt, $1 \mathrm{~h}$; c) HATU, $\mathrm{N}^{i} \mathrm{Pr}_{2} \mathrm{Et}, \mathrm{CH}_{2} \mathrm{Cl}_{2} / \mathrm{DMF}, 0^{\circ} \mathrm{C}$ - rt, $22 \mathrm{~h}, \mathbf{5 6}=61 \%, 57=66 \%$; d) Deoxo-Fluor ${ }^{\circ} \mathrm{CH}_{2} \mathrm{Cl}_{2},-20^{\circ} \mathrm{C}, 2 \mathrm{~h}$ then $\mathrm{DBU}, \mathrm{BrCCl}_{3},-20^{\circ} \mathrm{C}-0{ }^{\circ} \mathrm{C}$, $20 \mathrm{~h}(\mathbf{5 4}) / 15 \mathrm{~h}(\mathbf{5 5}), \mathbf{5 4}=69 \%, \mathbf{5 5}=92 \% . \mathrm{DMF}=\mathrm{N}, \mathrm{N}$-dimethylformamide.

\section{Synthesis of RHS fragment}

Synthesis of tetraoxazole fragment. The preparation of right hand side pentacycle 5 began with the preparation of tetracycle $\mathbf{9}$. This synthesis started by the coupling of Boc-protected isoleucine $\mathbf{1 6}$ with serine methyl ester hydrochloride $\mathbf{1 7}$ followed by cyclization and oxidation to install the first ring, with the remaining three rings being installed iteratively by the same process, affording tetracycle 9 in eleven steps and 10\% overall yield (scheme 15).

With the synthesis of tetraoxazole 9 successfully achieved, attention turned to whether this route could be improved by the use of multiple cyclizations in one step. However it was found that the synthesis of the cyclization precursors limited the number of rings we could attempt to form at once. While tripeptide $\mathbf{6 5}$ and diserine $\mathbf{6 6}$ could be obtained using standard solution phase coupling conditions, all attempts at gaining access to tri- or tetraserine containing molecules were unsuccessful, which could in part be due to the high polarity of these compounds and resulting solubility problems in organic solvents. When tripeptide 65 was submitted to the 
cyclization/oxidation conditions it was found that under optimised conditions only $23 \%$ dioxazole product 61 was formed, with the major product (61\%) being the dicyclised but only mono-oxidised product $\mathbf{6 7}$, which meant that the most efficient synthesis of dioxazole $\mathbf{6 1}$ would be the linear approach of scheme 15 .

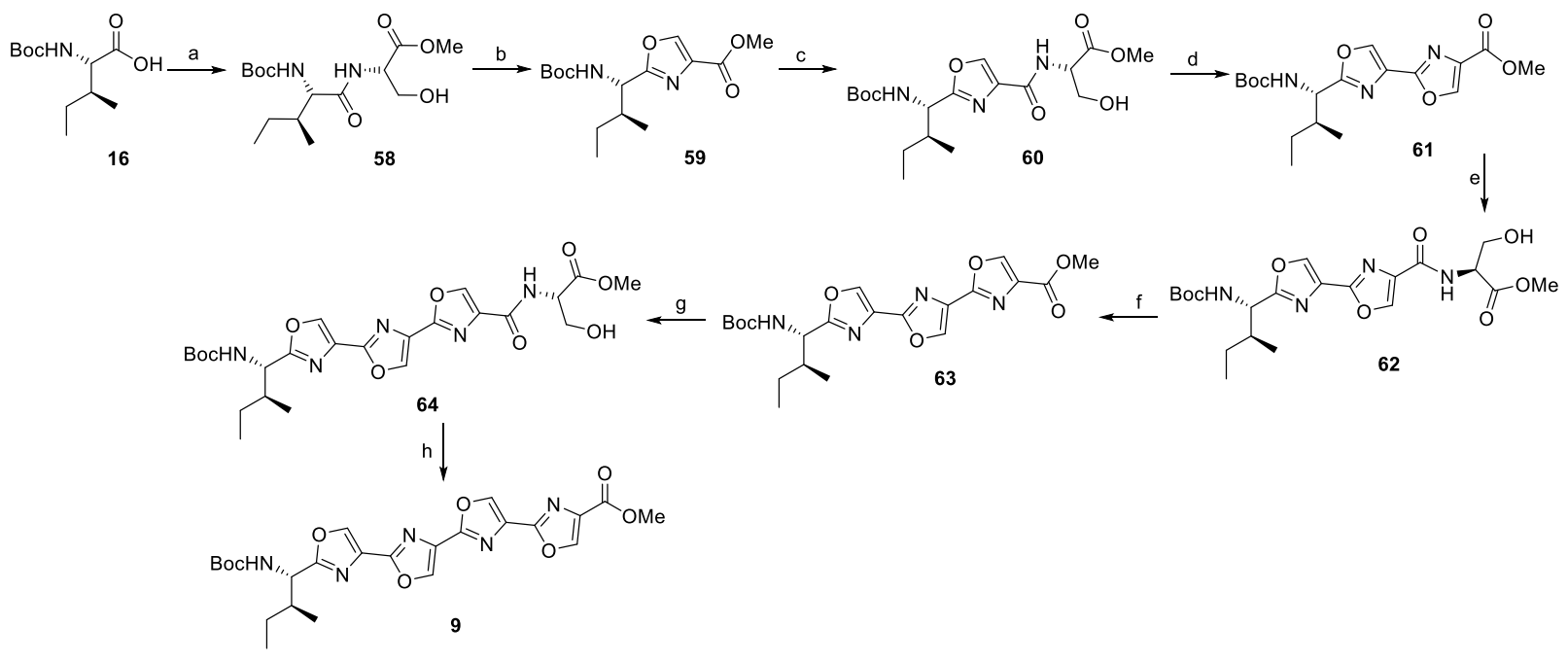

Scheme 15. Linear synthesis of tetraoxazole 9. a) Ser-OMe. $\mathrm{HCl}$ 17, $\mathrm{NiPr}{ }_{2} \mathrm{Et}, \mathrm{HOBt}, \mathrm{EDCl}, \mathrm{CH}_{2} \mathrm{Cl}_{2}, 20 \mathrm{~h}$, 91\%; b) Deoxo-Fluor, $\mathrm{CH}_{2} \mathrm{Cl}_{2},-20{ }^{\circ} \mathrm{C}, 30$ min then $\mathrm{BrCCl}_{3}, \mathrm{DBU},-20{ }^{\circ} \mathrm{C}-3{ }^{\circ} \mathrm{C}, 8 \mathrm{~h}, 81 \%$; c) i. LiOH. $\mathrm{H}_{2} \mathrm{O}$, THF/MeOH/ $\mathrm{H}_{2} \mathrm{O}, 0^{\circ} \mathrm{C}$ - rt, $18 \mathrm{~h}$, ii. Ser-OMe. $\mathrm{HCl} 17, \mathrm{~N}^{i} \mathrm{Pr}_{2} \mathrm{Et}, \mathrm{HOBt}, \mathrm{EDCl}, \mathrm{CH}_{2} \mathrm{Cl}_{2}, 20 \mathrm{~h}, 84 \%$; d) DeoxoFluor , $\mathrm{CH}_{2} \mathrm{Cl}_{2},-20{ }^{\circ} \mathrm{C}, 30$ min then $\mathrm{BrCCl}_{3}, \mathrm{DBU},-20^{\circ} \mathrm{C}-3{ }^{\circ} \mathrm{C}, 8 \mathrm{~h}, 78 \%$; e) i. LiOH. $\mathrm{H}_{2} \mathrm{O}$, $\mathrm{THF} / \mathrm{MeOH} / \mathrm{H}_{2} \mathrm{O}, \mathrm{O}^{\circ} \mathrm{C}, 3 \mathrm{~h}$, ii. Ser-OMe. $\mathrm{HCl} 17, \mathrm{~N}^{\prime} \mathrm{Pr}_{2} \mathrm{Et}, \mathrm{HOBt}, \mathrm{EDCl}, \mathrm{CH}_{2} \mathrm{Cl}_{2}, 20 \mathrm{~h}, 79 \%$; f) Deoxo-Fluor ${ }^{\circ}$, $\mathrm{CH}_{2} \mathrm{Cl}_{2},-20{ }^{\circ} \mathrm{C}, 30$ min then $\mathrm{BrCCl}_{3}, \mathrm{DBU},-20{ }^{\circ} \mathrm{C}-3{ }^{\circ} \mathrm{C}, 8 \mathrm{~h}, 73 \%$; g) i. LiOH. $\mathrm{H}_{2} \mathrm{O}$, THF/MeOH/ $\mathrm{H}_{2} \mathrm{O}, 0{ }^{\circ} \mathrm{C}$ - rt, 8 h, ii. Ser-OMe. $\mathrm{HCl} 17, \mathrm{~N}^{\prime} \mathrm{Pr}_{2} \mathrm{Et}, \mathrm{HOBt}, \mathrm{EDCl}, \mathrm{CH}_{2} \mathrm{Cl}_{2}, 20 \mathrm{~h}, 71 \%$; d) Deoxo-Fluor , $\mathrm{CH}_{2} \mathrm{Cl}_{2},-20^{\circ} \mathrm{C}$, 30 min then $\mathrm{BrCCl}_{3}, \mathrm{DBU},-20^{\circ} \mathrm{C}-3{ }^{\circ} \mathrm{C}, 6.5 \mathrm{~h}, 53 \%$.

The second dicyclization precursor $\mathbf{6 8}$ was synthesised by either coupling 61 and diserine 66, or by the less convergent coupling of dioxazole serine 64 with Ser-OMe. $\mathrm{HCl} 17$ (see supporting information). Pleasingly, dicyclization/oxidation of $\mathbf{6 8}$ proceeded in $\mathbf{7 7 \%}$ yield to afford tetraoxazole $\mathbf{9}$ in overall 47\% yield from 61, which is a marked improvement on the linear conversion of $\mathbf{6 1}$ to 9 which had an overall yield of $22 \%$, so this approach was incorporated into the final route (scheme 16).

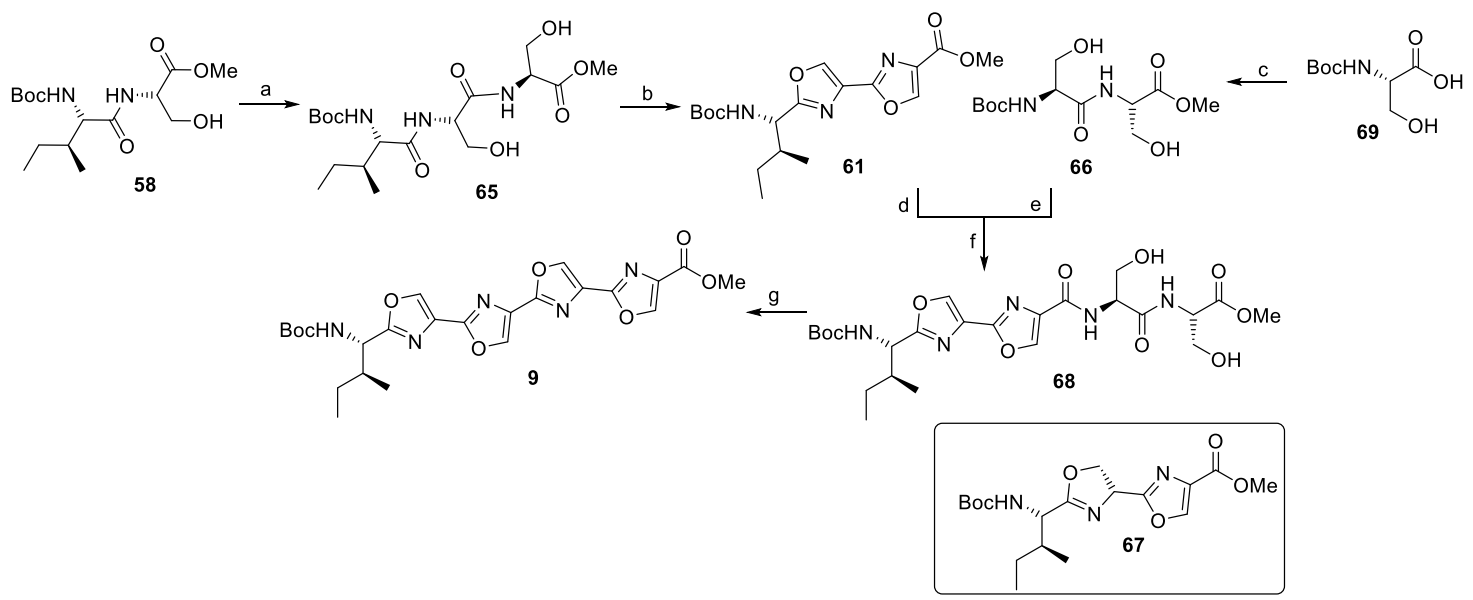


Scheme 16. Convergent synthesis of tetraoxazole 9. Reagents and conditions: a) i. LiOH. $\mathrm{H}_{2} \mathrm{O}$, $\mathrm{THF} / \mathrm{MeOH} / \mathrm{H}_{2} \mathrm{O}, 0^{\circ} \mathrm{C}, 2 \mathrm{~h} 45 \mathrm{~min}$, ii. Ser-OMe. $\mathrm{HCl} 17, \mathrm{~N}^{i} \mathrm{Pr}_{2} \mathrm{Et}, \mathrm{HOBt}, \mathrm{EDCl}, \mathrm{CH}_{2} \mathrm{Cl}_{2}, 20$ h, 74\%; b) Deoxo-Fluor , $\mathrm{CH}_{2} \mathrm{Cl}_{2},-20{ }^{\circ} \mathrm{C}, 1 \mathrm{~h} 45 \mathrm{~min}$ then $\mathrm{BrCCl}_{3}, \mathrm{DBU},-20^{\circ} \mathrm{C}--10{ }^{\circ} \mathrm{C}, 30 \mathrm{~min},-10{ }^{\circ} \mathrm{C}-0{ }^{\circ} \mathrm{C}, 6 \mathrm{~h}$, $23 \%$ (61) and 61\% (67); c) Ser-OMe.HCl 17, NiPr $\mathrm{Et}_{2} \mathrm{HOBt}, \mathrm{EDCl}, \mathrm{CH}_{2} \mathrm{Cl}_{2}, 20$ h, 88\%; d) . LiOH. $\mathrm{H}_{2} \mathrm{O}$, $\mathrm{THF} / \mathrm{MeOH} / \mathrm{H}_{2} \mathrm{O}, 0{ }^{\circ} \mathrm{C}$ - rt, $2 \mathrm{~h}$; e) anhydrous $\mathrm{HCl}$, 1.4-dioxane, $0{ }^{\circ} \mathrm{C}-\mathrm{rt}, 3.5 \mathrm{~h}$; f) $\mathrm{N}^{j} \mathrm{Pr}_{2} \mathrm{Et}, \mathrm{HOBt}, \mathrm{EDCl}$, $\mathrm{CH}_{2} \mathrm{Cl}_{2}, 20 \mathrm{~h}, 61 \%$; g) Deoxo-Fluor , $\mathrm{CH}_{2} \mathrm{Cl}_{2},-20{ }^{\circ} \mathrm{C}, 30$ min then $\mathrm{BrCCl}_{3}, \mathrm{DBU},-20{ }^{\circ} \mathrm{C}-0{ }^{\circ} \mathrm{C}, 8 \mathrm{~h}, 77 \%$.

It was found that tetraoxazole 9 was very poorly soluble, which proved problematic when the hydrolysis of the ester of this compound was attempted to enable progression, which was also observed by Süssmuth et al. for a similar intermediate in their work towards plantazolicin A (1). ${ }^{[11]}$ To try to avoid this problem, tetraoxazoles with ethyl ester $\mathbf{7 0}$ and benzyl ester $\mathbf{7 1}$ protection were obtained from trioxazole 63 (scheme 17).

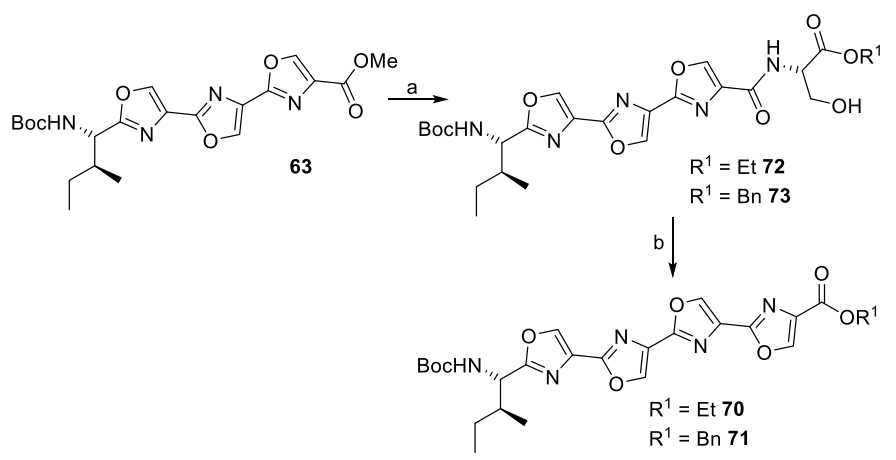

Scheme 17. Synthesis of alternatively protected tetraoxazoles $\mathbf{7 0}$ and $\mathbf{7 1}$. Reagents and conditions: a) i. LiOH. $\mathrm{H}_{2} \mathrm{O}, \mathrm{THF} / \mathrm{MeOH} / \mathrm{H}_{2} \mathrm{O}, \mathrm{O}^{\circ} \mathrm{C}$ - rt, 26 h, ii. Ser-OEt. HCl 74 (72)/Ser-OBn.HCl 75 (73), $\mathrm{N}^{i} \mathrm{Pr}_{2} \mathrm{Et}$, HOBt, EDCl, $\mathrm{CH}_{2} \mathrm{Cl}_{2}, 20 \mathrm{~h}, 72=90 \%, 73=84 \%$; b) Deoxo-Fluor ${ }^{\circ}, \mathrm{CH}_{2} \mathrm{Cl}_{2},-20^{\circ} \mathrm{C}, 30 \mathrm{~min}(\mathbf{7 0}) / 45 \mathrm{~min}$ (71) then $\mathrm{BrCCl}_{3}, \mathrm{DBU},-20{ }^{\circ} \mathrm{C}-0{ }^{\circ} \mathrm{C}, 20 \mathrm{~h}, 70=48 \%, 71=83 \%$.

Deprotection of the three tetraoxazoles was then attempted. Through use of high temperatures and mixed solvent systems it was found that both methyl ester $\mathbf{9}$ and ethyl ester $\mathbf{7 0}$ could be deprotected using lithium hydroxide, with methyl ester 9 being slightly higher yielding in initial tests, and was therefore carried forward (scheme 18). Multiple attempts at removing the benzyl ester of 71, both by hydrolysis and hydrogenation were unsuccessful, so this route was abandoned.

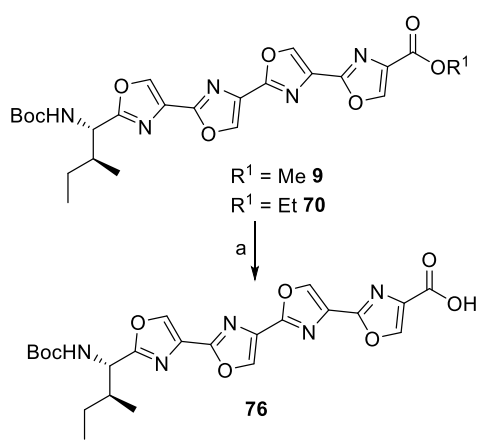

Scheme 18. Deprotection of tetraoxazoles 9 and 70. Reagents and conditions: a) $9-\mathrm{LiOH} . \mathrm{H}_{2} \mathrm{O}$, $\mathrm{THF} / \mathrm{MeOH} / \mathrm{H}_{2} \mathrm{O}, 0^{\circ} \mathrm{C}-\mathrm{rt}, 22 \mathrm{~h}, 62 \% * / 70-\mathrm{LiOH} . \mathrm{H}_{2} \mathrm{O}, \mathrm{CCl}{ }_{3} \mathrm{H} / \mathrm{MeOH} / \mathrm{H}_{2} \mathrm{O}, 50{ }^{\circ} \mathrm{C}-55^{\circ} \mathrm{C}, 19 \mathrm{~h}, 56 \% *$. *crude yields. 
Due to uncertainty over our overall protecting group strategies methoxy- (77), trimethylsilyl- (TMSE 78) and benzyl (10) esters of the required L-allo-threonine-phenylalanine dipeptide were synthesised to help establish what protecting group was most appropriate for the $C$-terminus (scheme 19).

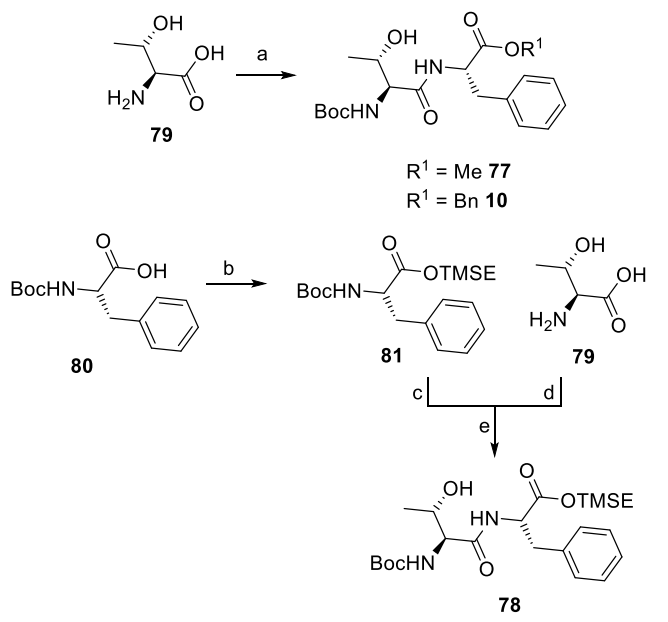

Scheme 19. Synthesis of $C$-terminus dipeptides. Reagents and conditions: a) i. $\mathrm{NaHCO}_{3}, \mathrm{H}_{2} \mathrm{O}$, rt, 15 min then $\mathrm{Boc}_{2} \mathrm{O}, \mathrm{MeOH}, \mathrm{rt}, 13.5 \mathrm{~h}$ (77)/13 h (10), ii. Phe-OMe. $\mathrm{HCl} 82$ (77)/Phe-OBn.HCl 19 (10),

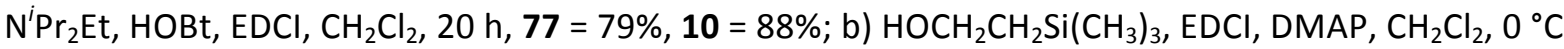
- rt, 18 h, 74\%; c) anhydrous $\mathrm{HCl}, 1$,4-dioxane, rt, $2 \mathrm{~h}$; d) $\mathrm{NaHCO}_{3}, \mathrm{H}_{2} \mathrm{O}, \mathrm{rt}, 15$ min then $\mathrm{Boc}_{2} \mathrm{O}, \mathrm{MeOH}$, rt, $15.5 \mathrm{~h}$; e) HATU, $\mathrm{N}^{i} \mathrm{Pr}_{2} \mathrm{Et}, \mathrm{CH}_{2} \mathrm{Cl}_{2}, 0{ }^{\circ} \mathrm{C}-\mathrm{rt}, 16 \mathrm{~h}, 81 \%$. DMAP = 4-dimethylaminopyridine.

These dipeptides were then coupled using HATU to the tetraoxazole 9 to give three potential right hand side coupling partners, $\mathbf{5}, \mathbf{8 3}$ and $\mathbf{8 4}$. Benzyl ester $\mathbf{5}$ was then dehydratively cyclised to the oxazoline 85 using diethylaminosulfur trifluoride (DAST) in a modest $39 \%$ yield. It was seen that the key coupling constant of the doublet of $5-\mathrm{MeOx}^{13}-\mathrm{C} 4 \mathrm{H}(4.32 \mathrm{ppm}, J=7.6 \mathrm{~Hz})$ correlated well to this coupling in the natural product $(4.23 \mathrm{ppm}, J=7.6 \mathrm{~Hz})^{[4 a]}$, which was a reassuring preliminary indication that the cyclodehydration was proceeding with inversion, consistent with an $\mathrm{S}_{\mathrm{N}} 2$-like ring closing mechanism (scheme 20). This was supported by the fact that when $\mathbf{8 6}$ was synthesised via an analogous route from natural L-threonine the coupling constant was considerably larger (4.78 ppm, $J$ $=10.0 \mathrm{~Hz}$ ) (see supporting information).

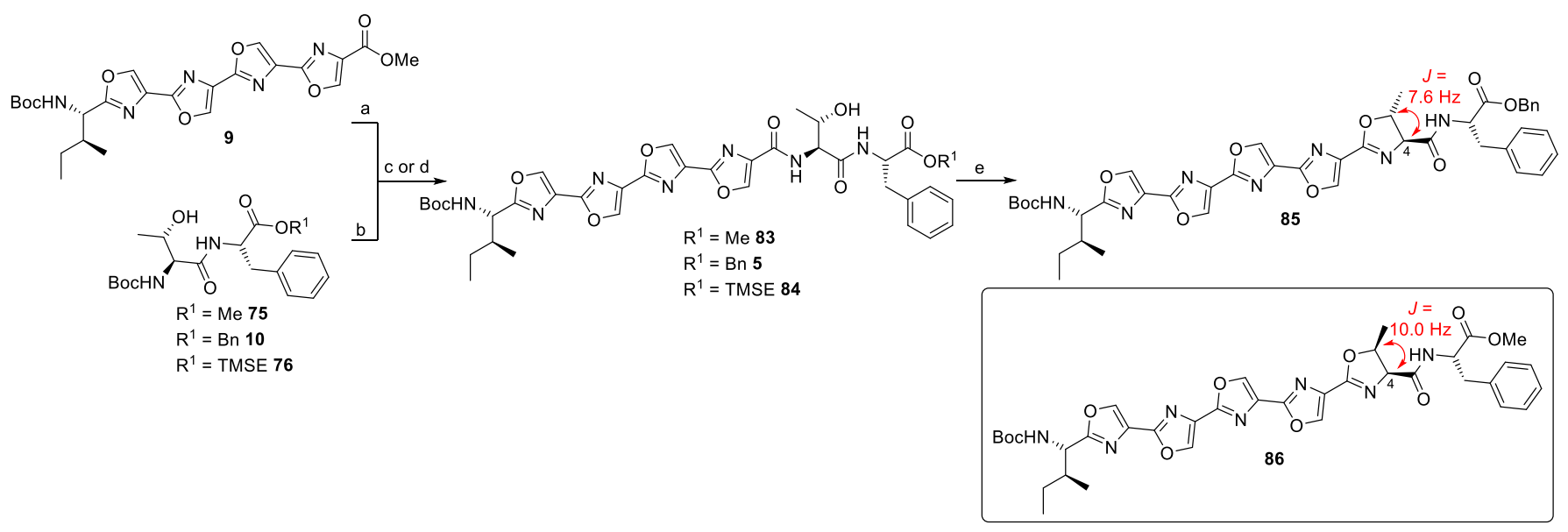


Scheme 20. Synthesis of right hand side coupling partners, showing key ${ }^{1} \mathrm{H}$ NMR coupling constant. Reagents and conditions: a) $\mathrm{LiOH} . \mathrm{H}_{2} \mathrm{O}, \mathrm{MeOH} / \mathrm{CHCl}_{3} / \mathrm{H}_{2} \mathrm{O}, 55^{\circ} \mathrm{C}-65^{\circ} \mathrm{C}, 7 \mathrm{~h}-2$ days; b) anhydrous $\mathrm{HCl}$, 1,4-dioxane, $0^{\circ} \mathrm{C}$ - rt, $30 \mathrm{~min}$; c) $\mathrm{N}^{i} \mathrm{Pr}_{2} \mathrm{Et}$, $\mathrm{HOBt}$, $\mathrm{EDCl}, \mathrm{CH}_{2} \mathrm{Cl}_{2}$, DMF (83 only) $20 \mathrm{~h}, 83=9 \%, 5=37 \%$; d) HATU, $N^{i} \mathrm{Pr}_{2} \mathrm{Et}, \mathrm{CH}_{2} \mathrm{Cl}_{2} / \mathrm{DMF}, 0{ }^{\circ} \mathrm{C}-\mathrm{rt}, 20 \mathrm{~h}(5) / 18 \mathrm{~h}(84), 5=60 \%, 84=77 \%$; e) DAST, $\mathrm{CH}_{2} \mathrm{Cl}_{2},-78{ }^{\circ} \mathrm{C}$, $1 \mathrm{~h}$ then $\mathrm{K}_{2} \mathrm{CO}_{3},-78{ }^{\circ} \mathrm{C}, 15 \mathrm{~min}$ then $\mathrm{rt}, 30 \mathrm{~min}, 39 \%(85)$.

\section{Coupling and completion}

Model coupling and deprotections. With the synthesis of the two left hand side fragments $\mathbf{5 4}$ and 55 and the right hand side with three different forms of $C$-terminus protection $\mathbf{5 , 8 3}$ and $\mathbf{8 4}$ successfully completed, next it was desirable to establish suitable conditions for the end game of the route using a model, before attempting it on the actual substrates.

Tri-azole $\mathbf{8}$ and dipeptide $\mathbf{1 0}$ were deprotected using the established conditions before coupling with HATU to afford the coupled product 87 in a modest $38 \%$ yield. The threonine residue of coupled model 87 was then dehydratively cyclised using Deoxo-Fluor ${ }^{\circ}$, as this had been reported to be more effective at cyclising threonine residues than DAST ${ }^{[12]}$, affording the oxazoline 88 in $74 \%$ yield. Attention then turned to the deprotection of the $C$ - and $N$ - termini where it was found that it was possible to remove the benzyl protecting group by hydrogenation with palladium " chloride, before trifluoroacetic acid (TFA) was used to remove the Boc protecting group and acetal to afford the deprotected product $\mathbf{8 9}$ in a crude $\mathbf{7 3 \%}$ yield (scheme 21 ). As the benzyl protecting group required an extra deprotection step, and the methyl ester removal conditions were unlikely to be compatible with the oxazoline ring, it was decided to progress the synthesis using TMSE protected right hand side 84 .

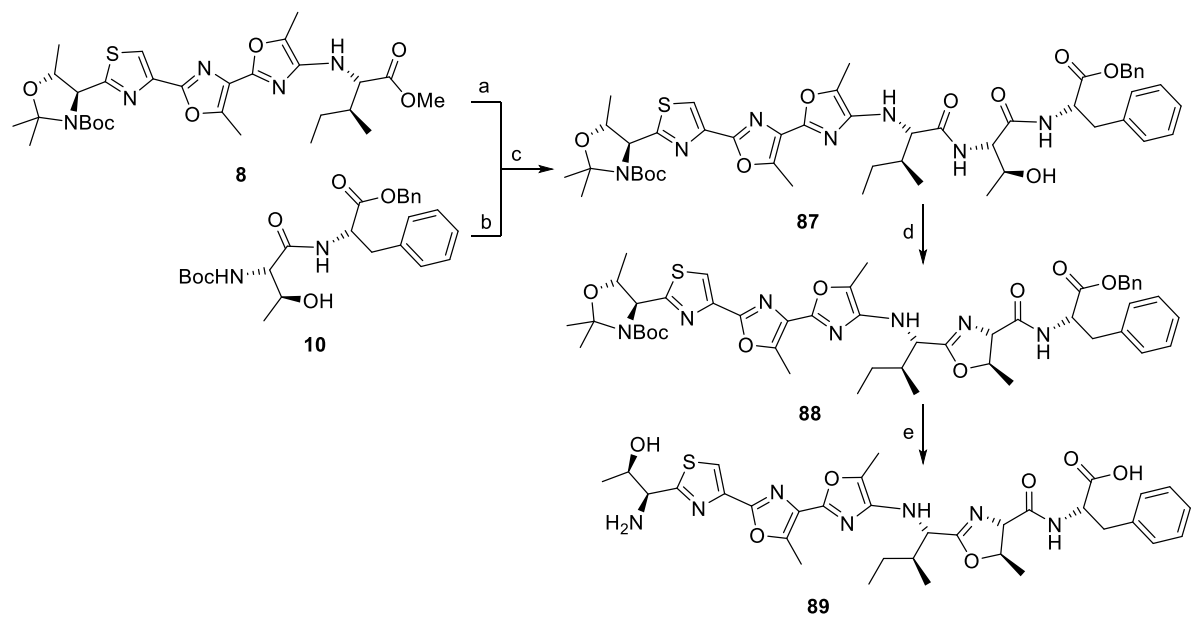

Scheme 21. Model system to investigate end game. Reagents and conditions: a) $\mathrm{LiOH}, \mathrm{MeOH} / \mathrm{H}_{2} \mathrm{O}$, $0{ }^{\circ} \mathrm{C}$ - rt, $19 \mathrm{~h}$; b) anhydrous $\mathrm{HCl}, 1$,4-dioxane, $0{ }^{\circ} \mathrm{C}-\mathrm{rt}, 30 \mathrm{~min}$; c) HATU, $\mathrm{N}^{i} \mathrm{Pr}_{2} \mathrm{Et}, \mathrm{CH}_{2} \mathrm{Cl}_{2} / \mathrm{DMF}, 0{ }^{\circ} \mathrm{C}-$ rt, 19 h, 38\%; d) Deoxo-Fluor , $\mathrm{CH}_{2} \mathrm{Cl}_{2},-20^{\circ} \mathrm{C}, 1$ h, 74\%; e) i. $\mathrm{PdCl}_{2}, \mathrm{H}_{2}, \mathrm{MeOH}, 2$ h, ii. TFA, $\mathrm{CH}_{2} \mathrm{Cl}_{2}, 6$ h, $73 \%$ (crude yield).

Coupling and completion of plantazolicin A and B. The coupling and cyclization conditions established using the model were then applied to the prepared plantazolicin coupling partners $\mathbf{5 4}$, $\mathbf{5 5}$ and $\mathbf{8 4}$ to afford the protected natural products $\mathbf{9 0}$ and $\mathbf{9 1}$. Pleasingly, it was found that treating these with neat TFA led to the removal of all protecting groups, as long as care was taken to exclude 
water to avoid the hydrolysis of the oxazoline ring (scheme 22). Purification was carried out using HPLC and full comparison of synthetic and natural plantazolicin $A$ is included in our communication of this work ${ }^{[10]}$ and Moody's synthesis of plantazolicin $A^{[6]}$ included a HPLC comparison of their synthetic 1 to material synthesised by this route. To the best of our knowledge the characterisation of biosynthetic precursor plantazolicin B (2) has not been carried out elsewhere.

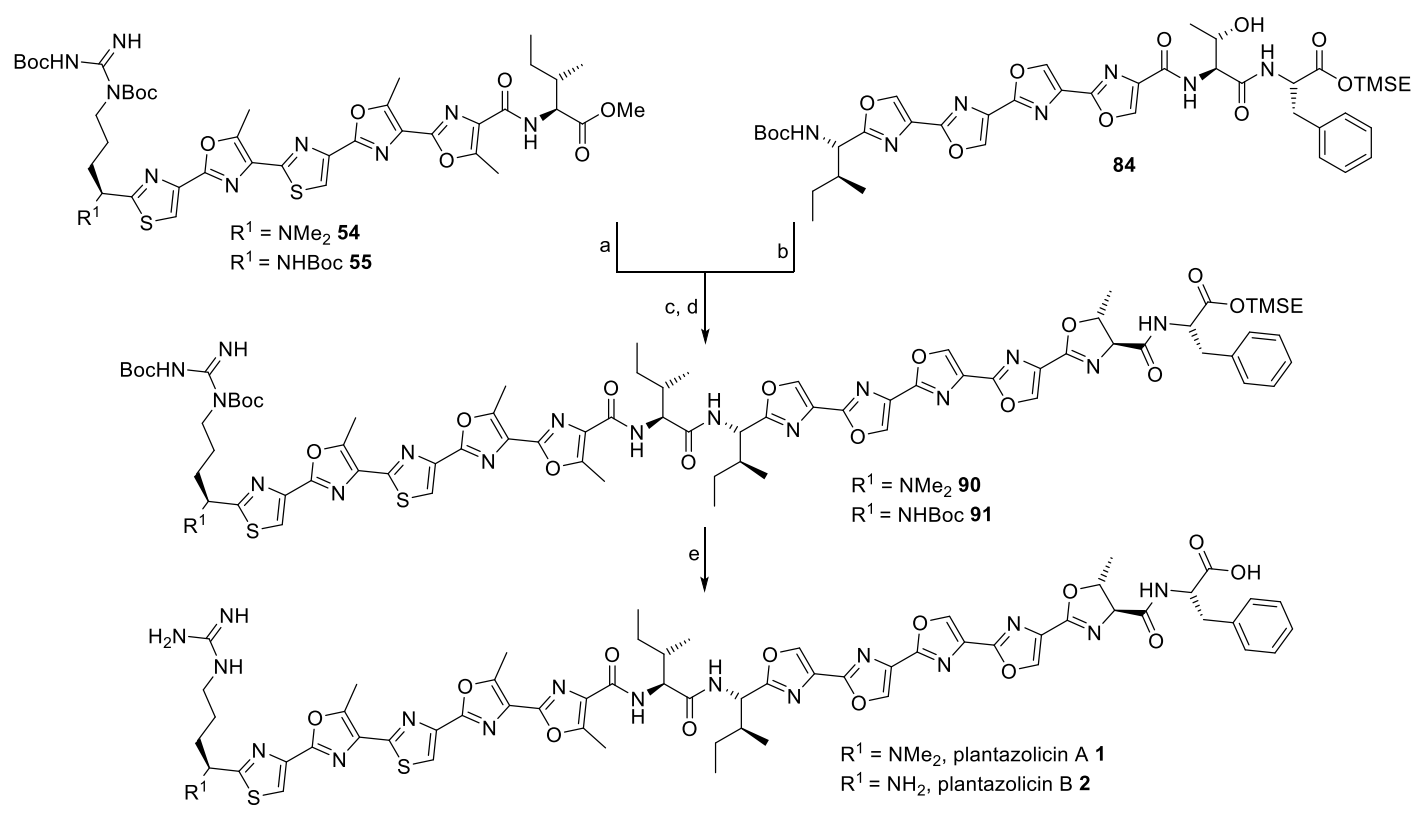

Scheme 22. Synthesis of plantazolicin A (1) and B (2). Reagents and conditions: a) $\mathrm{LiOH}, \mathrm{THF} / \mathrm{H}_{2} \mathrm{O}$, $0{ }^{\circ} \mathrm{C}$, 2 h $25 \mathrm{~min}$; b) anhydrous $\mathrm{HCl}$, 1,4-dioxane, $0{ }^{\circ} \mathrm{C}$ - rt, $30 \mathrm{~min}$; c) HATU, ${ }^{i} \mathrm{Pr}_{2} \mathrm{Et}_{1} \mathrm{CH}_{2} \mathrm{Cl}_{2} / \mathrm{DMF}, 0{ }^{\circ} \mathrm{C}$ - rt, 16 h; d) Deoxo-Fluor , $\mathrm{CH}_{2} \mathrm{Cl}_{2},-20^{\circ} \mathrm{C}, 24 \mathrm{~h}(\mathbf{9 0}) / 17 \mathrm{~h}(\mathbf{9 1}), 90=43 \%, 91=35 \%$; e) TFA, rt, $2 \mathrm{~h}(1) /$ 1h (2), $1=59 \%, 2$ = 64\%.

\section{Conclusions}

A comprehensive account of our investigations into the total syntheses of polyazole peptide natural product plantazolicin A, and its biosynthetic precursor plantazolicin B has been disclosed. The preparation of the challenging arginine derived thiazole fragments was achieved from natural amino acids and proved to be readily scalable. The synthesis of a variety of differently protected key fragments led to the development of an efficient overall protecting group strategy. Furthermore, the implementation of simultaneous cyclizations/oxidations allowed the convergent assembly of the polyoxazole subunits, leading to a step economic highly convergent overall synthesis of both plantazolicin A and B.

\section{Experimental Section}

Complete experimental details and characterisation for all compounds described in this manuscript can be found in the supporting information. Additional data related to this publication is available at the University of Cambridge Institutional Data Repository (http://dx.doi.org/10.17863/CAM.486).

\section{Acknowledgements}

We gratefully acknowledge generous funding from the German Academic Exchange Service DAAD (S.F.), The Royal Society (Newton International Fellowship - Z.E.W.), and the Engineering and Physical Sciences Research Council (grants EP/K009494/1 and EP/K039520/1). 
Keywords: plantazolicin $\bullet$ natural product $\bullet$ total synthesis $\bullet$ heterocycles $\bullet$ selective antibiotic

\section{References}

[1] D. J. Payne, Science 2008, 321, 1644-1645.

[2] D. J. Newman, G. M. Cragg, J. Nat. Prod. 2016, 79, 629-661.

[3] a) J. Lee, Y. Hao, P. M. Blair, J. O. Melby, V. Agarwal, B. J. Burkhart, S. K. Nair, D. A. Mitchell, Proc. Natl. Acad. Sci. U. S. A. 2013, 110, 12954-12959; b) N. A. Piwowarska, S. Banala, H. S.

Overkleeft, R. D. Süssmuth, Chem. Commun. 2013, 49, 10703-10705; c) A. Sharma, P. M. Blair, D. A. Mitchell, Org. Lett. 2013, 15, 5076-5079.

[4] a) B. Kalyon, S. E. Helaly, R. Scholz, J. Nachtigall, J. Vater, R. Borriss, R. D. Süssmuth, Org. Lett. 2011, 13, 2996-2999; b) R. Scholz, K. J. Molohon, J. Nachtigall, J. Vater, A. L. Markley, R. D. Süssmuth, D. A. Mitchell, R. Borriss, J. Bacteriol. 2011, 193, 215-224.

[5] C. A. Dunlap, S.-J. Kim, S.-W. Kwon, A. P. Rooney, Int. J. Syst. Evol. Microbiol. 2016, 66, 12121217.

[6] H. Wada, H. E. L. Williams, C. J. Moody, Angew. Chemie Int. Ed. 2015, 54, 15147-15151.

[7] a) K. J. Molohon, P. M. Blair, S. Park, J. R. Doroghazi, T. Maxson, J. R. Hershfield, K. M. Flatt, N. E. Schroeder, T. Ha, D. A. Mitchell, ACS Infect. Dis. 2016, 2, 207-220; b) R. C. Spencer, J. Clin. Pathol. 2003, 56, 182-187.

[8] K. J. Molohon, J. O. Melby, J. Lee, B. S. Evans, K. L. Dunbar, S. B. Bumpus, N. L. Kelleher, D. A. Mitchell, ACS Chem. Biol. 2011, 6, 1307-1313.

[9] Y. Hao, P. M. Blair, A. Sharma, D. A. Mitchell, S. K. Nair, ACS Chem. Biol. 2015, 10, 1209-1216.

[10] Z. E. Wilson, S. Fenner, S. V Ley, Angew. Chem., Int. Ed. 2015, 54, 1284-1288.

[11] S. Banala, P. Ensle, R. D. Süssmuth, Angew. Chem., Int. Ed. 2013, 52, 9518-9523. It should be noted that the natural product was not fully purified and some characterisation data was missing.

[12] A. J. Phillips, Y. Uto, P. Wipf, M. J. Reno, D. R. Williams, Org. Lett. 2000, 2, 1165-1168.

[13] a) E. Aguilar, A. I. Meyers, Tetrahedron Lett. 1994, 35, 2473-2476; b) M. W. Bredenkamp, C. W. Holzapfel, W. J. van Zyl, Synth. Commun. 1990, 20, 2235-2249; c) E. A. Merritt, M. C. Bagley, Synthesis (Stuttg) 2007, 3535-3541.

[14] G. Lajoie, F. Lepine, L. Maziak, B. Belleau, Tetrahedron Lett. 1983, 24, 3815-3818.

[15] a) H. T. Clarke, H. B. Gillespie, S. Z. Weisshaus, J. Am. Chem. Soc. 1933, 55, 4571-4587; b) W. Eschweiler, Berichte der Dtsch. Chem. Gesellschaft 1905, 38, 880-882; c) S. H. Pine, B. L. Sanchez, J. Org. Chem. 1971, 36, 829-832.

[16] R. F. Borch, M. D. Bernstein, H. D. Durst, J. Am. Chem. Soc. 1971, 93, 2897-2904.

[17] a) B. Di Credico, G. Reginato, L. Gonsalvi, M. Peruzzini, A. Rossin, Tetrahedron 2011, 67, 267274; b) Y. Hamada, M. Shibata, T. Sugiura, S. Kato, T. Shioiri, J. Org. Chem. 1987, 52, 1252-1255; c) M. P. Schubert, J. Biol. Chem. 1936, 114, 341-350.

[18] Z. Tian, L. Lis, S. R. Kass, J. Am. Chem. Soc. 2008, 130, 8-9. 
[19] K. C. Nicolaou, B. S. Safina, M. Zak, S. H. Lee, M. Nevalainen, M. Bella, A. A. Estrada, C. Funke, F. J. Zécri, S. Bulat, J. Am. Chem. Soc. 2005, 127, 11159-11175.

[20] S. Glockner, D. N. Tran, R. J. Ingham, S. Fenner, Z. E. Wilson, C. Battilocchio, S. V Ley, Org. Biomol. Chem. 2015, 13, 207-214. 